This article was downloaded by: [New York University]

On: 13 April 2015, At: 15: 12

Publisher: Routledge

Informa Ltd Registered in England and Wales Registered Number: 1072954

Registered office: Mortimer House, 37-41 Mortimer Street, London W1T

3J H, UK

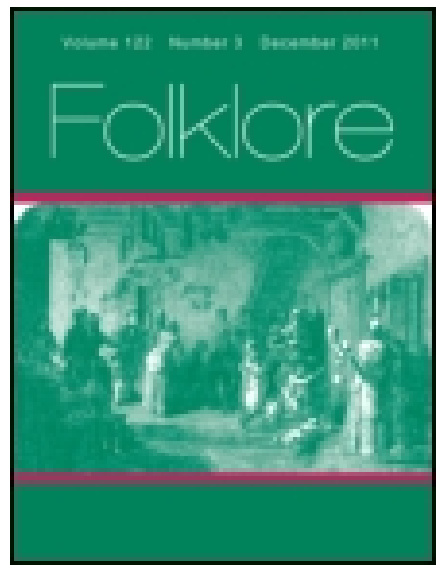

\title{
Folklore
}

Publication details, including instructions for authors and subscription information:

http:// www. tandfonline.com/loi/ rfol20

\section{Customs in the London Building Trade.}

Alice E. Milne

Published online: 06 Feb 2012.

To cite this article: Alice E. Milne (1900) Customs in the London Building Trade., Folklore, 11:4, 457-458, DOI: 10.1080/ 0015587X. 1900.9719600

To link to this article: http:// dx.doi.org/ 10.1080/ 0015587X.1900.9719600

\section{PLEASE SCROLL DOWN FOR ARTICLE}

Taylor \& Francis makes every effort to ensure the accuracy of all the information (the "Content") contained in the publications on our platform. However, Taylor \& Francis, our agents, and our licensors make no representations or warranties whatsoever as to the accuracy, completeness, or suitability for any purpose of the Content. Any opinions and views expressed in this publication are the opinions and views of the authors, and are not the views of or endorsed by Taylor \& Francis. The accuracy of the Content should not be relied upon and should be independently verified with primary sources of information. Taylor and Francis shall not be liable for any losses, actions, claims, proceedings, demands, costs, expenses, damages, and other liabilities whatsoever or howsoever caused arising directly or indirectly in connection with, in relation to or arising out of the use of the Content.

This article may be used for research, teaching, and private study purposes. Any substantial or systematic reproduction, redistribution, reselling, loan, sub-licensing, systematic supply, or distribution in any form to anyone is 
expressly forbidden. Terms $\&$ Conditions of access and use can be found at http://www.tandfonline.com/page/terms-and-conditions 
savage. It is difficult to analyse the primitive notion underlying this, but it seems to me that the practice of biting off the ears and tails of puppies, which is, I believe, usually followed by breeders, and is familiar to me from prosecutions by the Society for the Prevention of Cruelty to Animals, may be connected with it, and that the dogs' masters may originally have eaten the dogs' ears to render themselves more savage. It cannot be too much enforced on those who cut the ears and tails of dogs in England that they are executing an imperfect rite. Let them perform it in full, or not at all!

Cutting off Donkeys' Ears.-I had a reference, which I have mislaid, to a police case in Ireland, where a farmer was charged with cutting off a donkey's ears because it had trespassed in his crops. This custom was, and I fear still is, very common in Greece and the Greek Islands. It is of course not a mere act of vengeance, but what notion lies at the root of the abominable cruelty I cannot conceive.

W. R. Paton.

A gardener near Newport, Salop, cuts his cats' tails to keep them from trespassing in the woods. His predecessor cut one ear for the same reason. Frank Buckland (Curiosities of Natural History, and Series, ch. ii.) explains that this may be partly effectual, by allowing the wet to penetrate into the ear, to the animal's annoyance. $\quad$ C. S. BURNE.

At Cuzco, the ears of dogs used at funerals were cut off.-Int. Archiv. für Ethnog., viii., I44.

"Wenn die Kuh vom Bullen kommt, schneidet man ihr einen Schnitt ins Ohr; so wird sie tragend. (Mecklenburg.)" WUTrke, Der d. Volksaberglaube, 3rd Ed., § 698.

"Um den Hund vor Behexung zu schützen, haut man ihm den Schwanz ab. (Oldenburg.)"-Ibid., §680. N. W. Tromas.

\section{Customs in the London Building Trade.}

My little boy of four years old was taken one day lately to see the house now in building for us at Barnet. It had already been arranged that he should formally lay the date-stone when it was ready, but he wanted to be allowed to help at once, so the workmen good-naturedly let him lay a brick. As he was leaving the 
house afterwards, the head bricklayer called after the nurse, "The little boy will have no luck with the stone if he don't wet the brick!" When she told me this, I took back the child later in the day with a small coin to give to the friendly bricklayer who had superintended his work, and I found the words "No luck" scribbled upon the brick he had laid.

On our next visit to the house, we found that the words had been smudged out, but after the laying of the date-stone, which we were careful to "butter" with a variety of coins, we noticed that even the smears were carefully washed off.

In my native district (the borders of Shropshire and Staffordshire) this would have been called "paying his foot-ale."

The builder of 'our house tells us that when the first chimney is finished he himself will have to give the men a pint of ale apiece, after which they will hoist a flag on the roof-tree. If they do not get the ale, they will very likely hoist a black flag, and perhaps even refuse to continue the work.

$$
\text { Alice E. Milne. }
$$

\section{Another Sabbath-breaking Story from Wilts.}

\section{(Cf. p. 347.)}

There was a field near Warminster on which it always rained when the hay was cut. Years ago, the farmer, to induce his men to work on a Sunday in order to get his hay, hid his watch under the last haycock, pretended to have lost it, and set them to search for it. The hay-crop on that field has always been damaged by rain ever since, "so the old men used to tell me,". said G. W., a labouring man from Warminster, from whose narration I noted down this story in June, 1888 .

Charlotte S. Burne.

\section{Battle of Waterloo fought in England.}

Near Thirsk there is a field where folks say that the Battle of Waterloo (1) was fought, when the blood ran over the hoofs of the horses. 